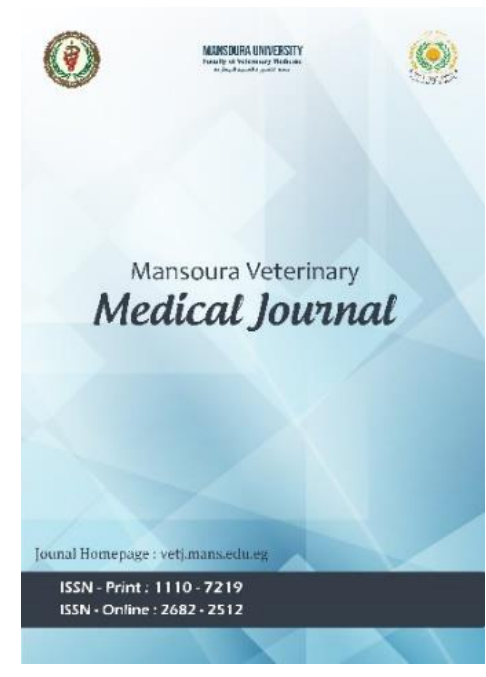

\title{
Incidence and molecular characterization of fungi and yeast isolated from cultured catfish and Nile tilapia
}

Ola, M. Hashem, Viola, H. Zaki, Rawia, S. Adawy

To cite this article: Ola, M. Hashem, Viola, H. Zaki, Rawia, S. Adawy . Incidence and molecular characterization of fungi and yeast isolated from cultured catfish and Nile tilapia. Mansoura Veterinary Medical Journal 2020; 21, 3: 61-66.

To link to this article: https://doi.org/10.35943/mvmj.2020.21.311

Published online: 29 September 2020

Submit your article to this journal

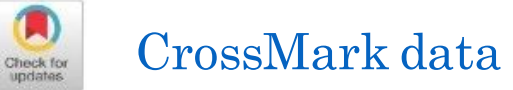




\section{Incidence and molecular characterization of fungi and yeast isolated from cultured catfish and Nile tilapia}

Ola, M. Hashem¹ ${ }^{1}$ Viola, H. Zaki², Rawia, S. Adawy ${ }^{1}$

${ }^{1}$ Animal Health Research Institute, Agriculture Research Center, Egypt

${ }^{2}$ Department of Internal Medicine, Infectious, and Fish Diseases, Faculty of Veterinary Medicine, Mansoura University, Mansoura, 35516

\section{ARTICLE HISTORY}

Received: 12.02 .2020

Revised: 04.06.2020

Accepted: 06.06.2020

Address correspondence to Ola Hashem; Tel: +201006112156; E-mail:

ola_hashem2015@yahoo.com

\begin{abstract}
Objective: To study the incidence and seasonal dynamics of different fungi affecting freshwater fishes in Lake Manzala as well as molecular identification of the isolated fungi.

Animals: 300 Nile tilapia (Oreochromis niloticus) and 300 catfish (Clarias gariepinus).

Design: Descriptive study.

Procedures: Random samples of Oreochromis niloticus (O. niloticus) and Clarias gariepinus (C. gariepinus) were collected from Manzala fish farms. Clinical and postmortem examination of fish was applied. Isolation and identification of different fungi were performed by conventional methods. Furthermore, the molecular characterization of isolated fungi was carried out.

Results: C. gariepinus had a higher rate of infection with different fungal species than $O$. niloticus. Aspergillus spp. (Aspergillus niger and Aspergillus flavus) were the most fungal isolated from the examined fishes, followed by Penicillium spp. and Candida albicans. Aspergillus spp were detected in all seasons with a higher rate in summer and spring. A. flavus, A. niger, Penicillium spp. and C.albicans isolates were amplified from both $C$. gariepinus and $O$. niloticus at the specified molecular weight using PCR.

Conclusion and clinical relevance: Fungal infection affected the fish showing different external and internal lesions, all species of Aspergillus were found in all seasons with a high rate in, hot seasons, summer and spring. The Prevalence of Penicillium and $C$. albicans were also reported. All fungal isolates were identified on the phenotypic and molecular bases.
\end{abstract}

Keywords: Fish, mold, yeast, PCR, isolation and identification.

\section{INTRODUCTION}

Fish is one of the most important sources of animal protein available in the tropics and a widely accepted as a good source for the maintenance of body health. Fish proteins are of a high degree of digestibility and richness of lysine and sulfur-containing amino acids. Therefore it is suitable for complementing high carbohydrate diets, especially in the developed countries [1].

With more intensification to meet consumers' demand, a major problem faced the progress and growth of this sector that fish often succumb to infectious diseases. Infectious fish dis eases not only caused bybacteria, viruses, or parasites but also could be mold-induced [2].

Fungal diseases are the result of the interaction of the pathogen, fish, and environment. Fish under intensive culture are conti nuously a ffected by water quality and ma nagement issues. Poor water quality, improper mangement, injured fish, or dead fish accompanied by large amounts of decomposing organic material are stressors that should be avoided to maintain fish health [3].

Molds grow over a temperature range of $10-40^{\circ} \mathrm{C}, \mathrm{pH}$ range of $4-8$, humi dity level greater than $62 \%$ and more than $12-13 \%$ moisture, while yeasts require free water [4].

Fish is mostly attacked by fungi due to changes in temperature, and water quality, which allow excessive zoospores to grow [5].

Molecular techniques have been increasingly employed to diagnose fish diseases. These techniques include polymerase chain reaction (PCR), restriction enzyme digestion, probe hybridization, in situ hybridization, and microarray. Molecular techniques are potentially faster and more sensitive than culture, serological, and histological methods that a re traditionally used to identify fish pathogens [6].

La ke Manzala is the la rgest coastal shallow brackish lake in Egypt, It is extending between the Damietta Nile River branch and the Suez Canal wi th a maximum length of $50 \mathrm{~km}$ along the Mediterranean coast [7]. The northern boundary of the lake is connected with some narrow inlets such as ElGamil canal with the sea. The eas tern boundary is Suez Canal that is connected with the lake via El-Qabuty canal. Economically, Lake Manzala is considered as one of the most valuable fish sources in Egypt by about $36-50 \%$ of the total annual production of the Egyptian lakes. This contributes $>$ $4.2 \%$ of the total country fish production; ca. 1.5 million tons [8]. Therefore, this work was planned to throw a spotlight on the prevalence and molecular identification of the fungal species isolated from Nile tilapia and catfish captured from Manzala fish farms.

\section{MATERIALS AND METHODS}

\subsection{Naturally infected fish}


A total number of 600 fishes, including 300 Nile tilapia and 300 Nile catfish, were collected from Manzala fish farms in Dakahlia Governorate, Egypt. The fish samples were collected during the period from April 2018 to March 2019. Fish were transported alive in a polyethylene bag to the laboratory of Animal Health Research Institute in Mansoura for mycological examination.

\subsection{Clinical and postmortem examination:}

Moribund and diseased fish were properly examined for any external clinical abnormalities and clinical a lterations on the skin, scales, eyes, gills, abdomen, peduncle, fins, and abnormal behaviors. The pos tmortem examination was done on freshly dead fish to examine, all internal organs including liver, spleen, kidney and intestine, the clinical investigation and postmortem examination were carried out according to Austin and Austin [9].

\subsection{Mycological examination}

\subsubsection{Isolation and identification of the fungi from infected} fish

Samples were taken from fish showing skin lesions using a sterile dissecting needle from the skin, gills, and internal organs (liver, kidney). Collected specimens were inoculated into duplicate plates of SDA media $500 \mathrm{mg}$ of cycloheximide and $50 \mathrm{mg}$ of chloramphenicol dissolved in $3 \mathrm{ml}$ etha nol $95 \%$ were added to the media after a utoclaving). The inoculated plates were incubated at $25^{\circ} \mathrm{C}$ and $37^{\circ} \mathrm{C}$ for $3-5$ days. Pure isolates obtained from culture were preserved on Sabouraud's dextrose agar slants for further identification [10]. Fungal colonies were examined macroscopically for growth appearance, growth rate, the surface colony texture, surface colonies color, as well as the reverse side of the colonies were observed [11]. Additionally, a microscopic examination of the culturewas carried out after staining with lactophenol cotton blue (LPCB) [12].

\subsubsection{Isolation and identification of yeast species:}

Yeast i solates were picked up with a sterile loop from preserved culture ontoSDA slopes. Identification was carried out through the morphological and physiological properties of the yeast is olates and direct microscopic exa mination. For direct microscopic examination, a part of the colony was placed on a slide with one drop of distilled water, and covered with a coverslip and examined under high power magnification after staining with Gram-stain [13].

\subsection{Molecular identification of fungal isolates:}

DNA extraction using Qiagen extraction kit was performed according to the manufacturer instructions.For identification of fungal isolates, PCR was performed for identification of $A$. flavus, A.niger, Penicillium spp. and C.albicans using PEPO1-PEPO2, PEPI1-PEPI2, ITS1-ITS4, and LH1-LH2 primers respectively. Primer details were summarized in Table. 1. PCRs were performed in thermal cycler and the thermal conditions were des cribed in Table 2 . The amplified products were analyzed by electrophoresis on a $1 \%$ agarose gel and visualized by ethidium bromide staining using a UV transilluminator.

\section{RESULTS}

\subsection{Clinical examination and postmortem lesions}

The infected $C$. gariepin us catfish showed skin ulceration and scattered hemorrhagic patches on the ventral abdomen and mouth, while the external gross lesions of the exa mined Nile tilapia revealed darkened skin, severe congestion and sloughing of the tail fin with ascites, scale detachment and fins erosion.

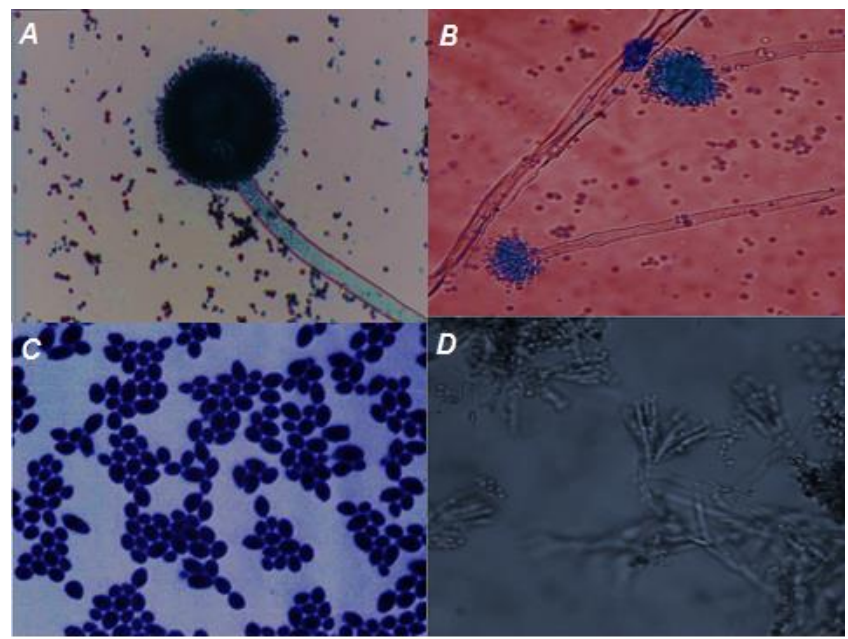

Figure 1. A) A. niger: the conidiophores are very long, smooth and the vesicles are very large and globes while the strigmata were biseriate, compact and radiate. The conidia are globes and smooth. B) A. flavus: the conidiophore s were long and rough. The vesicles are large and rounded. The strigmata are biseriate, loose, and radiate and gave rise to ovoid rough conidia. C) penicillium:Septate hyphae with branched condiospores possessing metule with flask shape and the formed brush appearance strigmata (lactophenol blue staining/LPCB, $\times 400)$. D) C. albicanis: small, oval, measuring 2-4 $\mu \mathrm{m}$ in diameter Yeast form, unicellular, reproduce by budding. Both yeast and pseudo-hyphae are gram positive. Encapsulated and diploid, also form true hyphae.

Out of the total examined fish samples collected from Manzala fish farms, 121 fish were tested positive for fungal detection in a prevalence rate of $20.1 \%$. The is olation rate of fungi from catfish was higher (22.3\%) than that of $O$. nilotias Nile tilapia (18\%). The frequency of $A$. niger, $A$. flavus, Penicillium spp. and $C$. albicans in C.gariepinus and $O$. niloticus was (17.9, 16.6\%), (14.9, 12.9\%), (13.4, $11.1 \%)$ and $(8.9,11.1 \%)$ respectively.

Regarding the frequency of $A$. niger, $A$. flavus, Penicillium spp. and $C$. albicans in relation to different seasons, in a utumn, the prevalence rate was (13.3 \&14.2\%), (6.6\&7.1\%), (13.3 \& $7.1 \%)$, and (13.3 \& $21.4 \%$ ) from C.gariepinus and O.niloticus, respectively. While, in spring, the prevalence of $A$. niger, A. flavus, Penicillium spp. in C. gariepinus, and O.niloticus was (21.4 \& $18.1 \%),(28.5 \& 27.2 \%)$ and $(21.4 \&$ $18.1 \%)$ respectively, meanwhile $C$. albicans couldn't be detected. The prevalence of $A$. niger, $A$. flavus, and C.albicans during the summer season was (30\&20\%), (20 \&10\%), and (10 \& 10\%) for both C. gariepinus and $O$. nilotiaus respectively. 

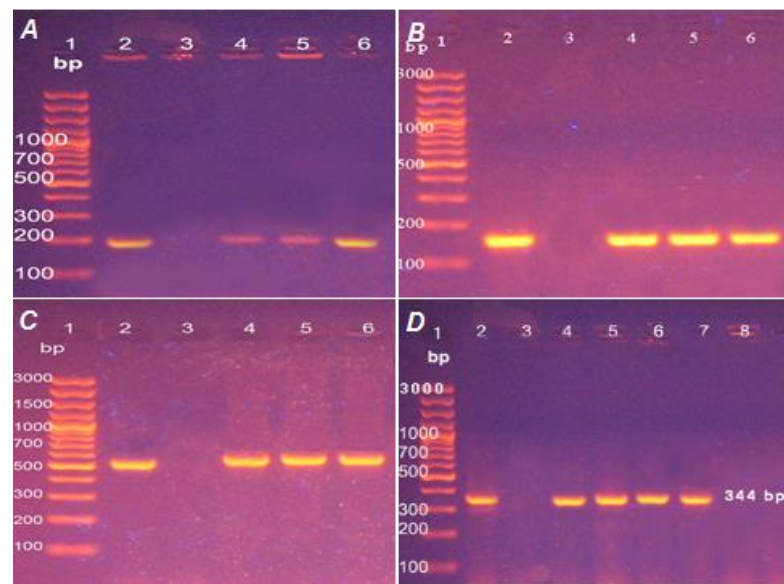

Figure 2. Agarose gel electrophoresis of positive amplicons of A) A. niger (150 pb): Lane 1: 100 bp DNA Ladder, Lane 2, 4, 5, 6 positive $A$. niger isolates. B) $\boldsymbol{A}$ flavus (200 pb): Lane 1: $100 \mathrm{bp}$ DNA ladder, Lane $2,4,5,6$ positive $A$. flavus, isolates. C) penicillium (550 pb): Lane 1: $100 \mathrm{bp}$ DNA ladder, Lane 2,4,5,6: positive penicillium isolates. D) C. albicanis (344 pb): Lane 1: 100 bp DNA ladder, Lane $2,4,5,6,7$ positive $C$. albicans isolates.

\subsection{Morphological characters of the isolated fungi}

A. niger characterized by long conidiophores, large vesicle, and biseriate, compact radiated strigmata, and conidia a re gl obes and smooth. $A$. flavus has long a nd rough conidiophore, large and rounded vesicle, and a re biseriate, loose, and radiate strigmata and gave rise to rough ovoid conidia. While Penicillium spp. showed a septate hyphae with branched conidiospores possessing metule with flask shape and formed brush appearance Strigmata. However, $C$. albicans is small, oval budding yeast cells measuring $2-4 \mu \mathrm{m}$ in diameter (Figure 1).

Table 1. Primers used in PCR detection of fungal isolates.

\begin{tabular}{|c|c|c|c|c|}
\hline Species & $\begin{array}{l}\text { Primer } \\
\text { pairs }\end{array}$ & Sequence $\left(5^{\prime} \rightarrow 3^{\prime}\right)$ & $\begin{array}{l}\text { Amplicon } \\
\text { size (bp) }\end{array}$ & References \\
\hline \multirow{2}{*}{ A. flavus } & F: PEPO1 & CGACGTCTACAAGCCTTCTGGAAA & $\sim 200 \mathrm{bp}$ & \multirow{4}{*}{ [38] } \\
\hline & R: PEPO2 & CAGCAGACCGTCATTGTTCTTGTC & & \\
\hline \multirow{2}{*}{ A. niger } & F: PEPI1 & CCAGTACGTGGTCTTCAACTC & \multirow{2}{*}{$\sim 150 \mathrm{bp}$} & \\
\hline & $\begin{array}{l}\text { R: PEPI2 } \\
\text { F: LH1 }\end{array}$ & CTATTGTACCTTGTTGCTTCGGCG & & \\
\hline Candida albicanis & $\mathrm{R}: \mathrm{LH} 2$ & AGC CACAACAAC AAC AACAAC TCT TTGAGA AGG ATC TTT CCA TTG ATG & $344 \mathrm{bp}$ & [39] \\
\hline penicillum & $\begin{array}{l}F: I T S 1 \\
\text { R: ITS4 }\end{array}$ & TCCGTAGGTGAACCTGCGG TCCTCCGCTTTATTGATATG & variable & [40] \\
\hline
\end{tabular}

Table 2. PCR thermal conditions for A. favus, A. niger, C. albicanis and penicillium.

\begin{tabular}{|c|c|c|c|}
\hline Amplified DNA & $\begin{array}{l}\text { Initial denaturation } \\
{ }^{\circ} \mathrm{C} / \text { minutes }\end{array}$ & Actual cycles ${ }^{\circ} \mathrm{C} /$ second & $\begin{array}{l}\text { Final } \\
\text { extension } \\
{ }^{\circ} \mathrm{C} / \text { minutes }\end{array}$ \\
\hline A. favus and A. niger & $94 / 5$ & $\begin{array}{l}38 \text { cycles of } \\
\text { Denaturation: } 94 / 60 \\
\text { Annealing: } 59 / 60 \\
\text { Extension: } 72 / 90\end{array}$ & $72 / 5$ \\
\hline C. albicans & $92 / 3$ & $\begin{array}{l}35 \text { cycles of } \\
\text { Denaturation: } 92 / 60 \\
\text { Annealing: } 55 / 60 \\
\text { Extension: } 72 / 60\end{array}$ & $72 / 10$ \\
\hline Penicillium spp. & $94 / 4$ & $\begin{array}{l}35 \text { cycles of } \\
\text { Denaturation: } 94 / 60 \\
\text { Annealing: } 56 / 60 \\
\text { Extension: } 72 / 60\end{array}$ & $72 / 10$ \\
\hline
\end{tabular}

successfully amplified from all the tested isolates using one pair of primers targeting the integrin-like protein alpha-INT1p (Figure5).

\subsection{Molecular identification of isolated fungi}

The $A$. flavus $(n=3)$ were successfully amplified, producing a 200 bpamplicon (Figure 2). A. niger ( $n=3)$ strains were amplified, yi elding fragment size of $150 \mathrm{bp}$ (Figure 3). Penicillium spp. isolates $(n=4)$ were amplified at a $550 \mathrm{bp}$ amplicon size (Figure 4). For identification of $C$. albicanis $(n=4)$, a product size of $344 \mathrm{bp}$ was

\section{DISCUSSION}

The clinical examination of the infected fish, C. gariepinus, revealed skin ulceration and scattered hemorrhagic patches on the ventral abdomen and mouth. These symptoms may be attributed to the toxins secreted by molds and yeasts causing severe symptomatic changes that appeared on the fish in the 
form of hemorrhagic patches, ascites and destruction and degeneration of the gills; the results agreed with that of previous reports [5], [14] and [15]

The external gross lesions of the examined $O$. niloticus revealed darkened skin, severe congestion, and sloughing of the tail fin with ascites, scale detachment, fins erosion, and eye opacity. These results a re in agreements with $[14,16]$. Gills with sever congestion considered as secondary invader pathogen; these results agreed with many authors $[15,17-$ 19].

Fish mortalities may be due to either blindness, which cons equently disables fish to feed or due to the fungal growth over gills causing suffocation. The ulcerative areas over the skin may be attributed to the lytic action of primary bacterial infection since fungal infections a re considered as secondary invader pathogens to the bacterial ones. These results were supported by many previous studies $[15,18,19]$.

In the current study, out of the whole examined fish, only 121 fish were infected with different fungi at a rate of $20.1 \%$. C. gariepinus recorded a higher incidence (22.3\%) than O. niloticus (18\%). In contrast to our results, a higher frequency of fungi was recorded in O. niloticus by Diab [14]. Also Refai et al. [20] and Ma hfouz et al. [15] recorded higher incidence in 0 . niloticus ( $80.5 \% \& 56.8 \%$ ) than C. gariepinus (78.2 \% \& $43.1 \%$ ), respectively. The va riation of the infection rate might be due to the scale-less na ture of the catfish skin, as suggested by Hussien et al. [21], who reported that scales covered the fish skin act as a physical barrier against external pathogens.

The incidence of the isolated fungi from both species of fishes $C$. gariepinus and $O$. niloticus was as follow; $A$. niger ( 17.9 \& $14.8 \%$ ), A. flavus ( 15.2 \& 12.1\%), Penicillium spp.( $11.9 \& 12.9 \%$ ) and Candida albicans ( $8.9 \& 9.2 \%$ ) res pectively. Similarly, a similar prevalence of Penicillium spp (17.2\%) a nd a higher prevalence of Candida spp. (35.9\%) were reported previously [22]. However, a higher prevalence of Penicillium spp. (70\%) was recorded by Hassan et al. [23], additionally, A higher prevalence of Aspergillus spp. (90\%) and Candida spp. (70\%) from El- Wadi El-Gadid and El Fayome governorates was reported previously [24].

Concerning the seasonal dynamics of infection, winter seas on showed a high rate of infection in both $C$. gariepinus (31.1\%) and 0 . niloticus (23.1\%), foll owed by autumn (25 \&19.4 \%) spring (17.2 \&15.4 \%) and summer (14.2\&13.1\%). These results were supported by Moeller [25], who mentioned that the most epizootic infection occurs when temperatures are below the optimal temperature range for fish species and might be due to sudden changes in temperature [26] and [27] as observed during the a utumn season in the present study.

Aspergillus spp. was found all over the year with high incidence (30 \&20\%) in both C. gariepinus and O. niloticus, respectively, in summer (hot season). The infection rate for A. niger and $A$. flavus during the summer season was ( $20 \& 10$ $\%),(10 \& 30 \%)$, res pectively, in both examined fish species,
Same findings were supported in many previous studies [14, $20,28]$. The prevalence of Penicillium spp. was high in summer and spring, which in agreement with Mahfouz et al. [15]. C.albicans was isolated during all seasons but not detected in spring. C.albicans recorded high incidence in autumn (13.3 \& $21.4 \%$ ) followed by winter (10.7 \& $10.5 \%)$ and spring (10 \& $10 \%)$ in both examined fishspecies, in line with Mahfouz et al. [15].

Concerning the results of the molecular identification of Aspergillus spp., A. flavus ( $\mathrm{n}=3$ ) produced a $200 \mathrm{bp}$ a mplicon. $A$. flavus strains were successfully amplified by the PEPO1PEPO2 primer set. $A$. niger $(n=3)$ strains were amplified by the specific primer pair (PEPI1-PEPI2), yielding fragment in size (150 bp) PCR products. The obtained results were comparable to that recorded by Logotheti et al. [29] who mentioned that the multiplex PCR assay for the discrimination of the most frequent Aspergillus pathogens, $A$. flavus and $A$. niger through distinct a mplicons of $200 \mathrm{bp}$, and $150 \mathrm{bp}$ respectively, derived from the rDNA gene of $A$. terreus and the aspergillopepsin genes of the remaining species.

The molecular detection of Penicillium spp., all isolates amplified using primers ITS1 and ITS4 to a single band of a bout 550 bp except two species, Penicillium variable showed slight increases band about 565 bp in size, whereas Penicillium rugulosum showed a band of size $540 \mathrm{bp}$, which was lowest in our study. Similarly, Tiwari et al. [31], stated that the consensus primers ITS1 and ITS4 were used to a mplify a region of the rDNA gene repeat unit. A recent study of Penicillium isolates based on the ba nding pattern of the ITS region has shown a more similarity a mong different species of Penicillium.

For C. albicans, one pair of primers (LH1- LH2) was selected for specific identification of this species. In the same line, Lim and Do-Hyun [32] identified 26 isolates of $C$. albicans from clinical samples yielding the same product size of 344 bp, while about 15 clinical i solates couldn't be a mplified. The PCR system using 344 bp alNT1 as a target is more specific and rapid than the conventional culture method, and the sensitive detection method is applicable to clinical diagnosis of $C$. albicans infections.

Many studies reported that the ITS2 showed considerable interspecies variability to identify $99.7 \%$ of yeasts and $100 \%$ of molds to the species level, while ITS1 had an identification accuracy of $96.8 \%-100 \%$ for yeasts and $100 \%$ for molds [33]. Further, PCR-RFLP as says have been used to identify the isolated yeast s pecies as was successfully done [34]

Yang et al. [35] stated that phenotypic methods are valuable in the identification of yea sts into genera, but these methods take more time. Molecular methods through the amplification of (internal transcribed spacer) ITS1-ITS2 regions of fungal rRNA, followed by RFLP-PCR using Msp1 restriction enzyme allowed simple, rapid, cost-effective, sensitive, and accurate identification of the phenotypically. 


\section{Conclusion}

Fungal infection affected the fish showing different external and internal lesions, all species of Aspergillus were found in all seasons with a high rate in, hot seasons, summer and spring. Prevalences of Penicillium and C. albicans were also reported. All fungal isolates were identified on the phenotypic and molecular bases .

\section{Conflict of interest statement}

\section{The authors declare no conflict of interest}

\section{Research Ethics Committee Permission}

The current research work was executed according to animal care regulations approved by o the Res earch Ethics Committee, Faculty of Veterinary Medicine, Mansoura University.

\section{Authors' contributions}

O.M.H. conducted the procedure of res earch and drafted the MS; R.S.A. supervised the study. V.H.Z. supervised, reviewing and editing the MS.

\section{REFERENCES}

[1] Andrew A.E. Fish processing technology. University of Ilorin press, Nigeria. 2001;7-8.

[2] Bassey S. A Concise Dictionary of Parasitology. Zetus Concepts, 978-40. 2011;3(1):115.

[3] Ramaiah N. A review on fungal diseases of algae, marine fishes, shrimps and corals; 2006 .

[4] Lacey J. Natural occurrence of mycotoxins in growing and conserved forage crops.1991;363-97.

[5] Chauhan R, Lone S, Beigh A. Pathogenecity of three species of Aspergillus (A. fumigatus, A. niger \& A. sydowii) on some fresh water fishes. Life Sci Leaf. 2014;48:65-72.

[6]Altinok i, Kurt IJ. Molecular diagnosis of fish diseases: a review. Turkish J Fish Aqua Sci 2003;3(2):131-8.

[7]Ahmed MH, El Leithy BM, Thompson JR, Flower RJ, Ramdani M, Ayache F, et al. Application of remote sensing to site characterisation and environmental change analysis of North African coastal lagoons. Hydrobiologia. 2009;622:147-71. https://doi.org/10.1007/s10750008-9682-8

[8]Rasmussen EK, Petersen OS, Thompson J, Flower R, Ahmed $M$. Hydrodynamic-ecological model analyses of the water quality of Lake Manzala (Nile Delta,Northern Egypt). Hydrobiologia. 2009;622:195. https://doi.org/10.1007/s10750-008-9683-7

[9]Austin B, Austin DA, Austin B, Austin DA. Bacterial fish pathogens: Springer; 2012. https://doi.org/10.1007/978-94-007-4884-2

[10] Shaheen A. Mycoflora of some freshwater fish. M.V. Sc: Thesis, Fac. Vet Med., Zagazic Univ; 1986.

[11] Frey D, Oldfield RJ, Bridger RC. A colour atlas of pathogenic fungi: Wolfe Medical Publications Ltd., Wolfe House, 3-5 Conway Street, London W1P 6HE; 1979.

[12] Dvořák J, Otčenášek M. Mycological Diagnosis of Animal $\begin{array}{lll}\text { Dermatophytoses. } & \text { Springer } \quad \text { Netherlands; } & 1969 .\end{array}$ https://doi.org/10.1007/978-94-010-3426-5

[13] Refai M, Gobba A, Rieth H. Monograph on yeasts. Diagnosis, diseases, and treatment. Vet Med J Giza. 1969;16(17):255-316.

[14] Diab AMA. Studies on the mycological affections in cultured fresh water fishes in Kafr El-Sheikh governorate M.V.Sc Thesis (Fish diseases and management). 2006.

[15] Mahfouz N, Moustafa E, Kassab M, Marzouk W. Sesonal screening of the mycotic innfections of cultured freshwater fishes in kafr El-Sheikh governorate. Sloveniann Veterinary research. 2019;56(22-Suppl). https://doi.org/10.26873/SVR-771-2019
16] Marzouk MS, Samira SR, El-Gamal MH. Mycological investigations on cultured Tilapia in Kafer El-Sheikh Governorate. 2003:97-111. J. 59 (37): 57-65.

[17]El-Atta M.E.A. Saprolegniosis in freshwater cultured tilapia nilotica (Orechromis niloticus) and trial for control by using Bafry D50/500. Proceedings of the 8th International Symposium on Tilapia in Aquaculture.2008; Cairo, Egypt, pp: 1403-1418.

[18] Ganguly S, Wakchaure R, Mahajan T, Praveen K. Most Dreadful and Fatal Equine Infections of Worldwide Occurrence: A Brief Review. Inter J Live Res 2017:1. https://doi.org/10.5455/ijlr.20160930083845

[19] El-Deen AN, Osman HM, Zaki MS, AlyAbo-State H. Mass Mortality in Cultured Nile Tilapia Oreochromis niloticus in Kafr El-Sheikh Province, Egypt Due to Saprolegniosis with Emphasis on Treatment Trials. J Bio Sci 2018;18(1):39-45. https://doi.org/10.3923/jbs.2018.39.45

[20] Mohamed HM, Emeish WF, Braeuning A, Hammad S. Detection of aflatoxin-producing fungi isolated from Nile tilapia and fish feed. EXCLI J 2017;16:1308.

[21] Refai M, Laila K, Amany M, Shimaa E-S. The assessment of mycotic settlement of freshwater fishes in Egypt.J Amer Sci2010;6(11):823-31.

https://www.researchgate.net/publication/260403877_The_Assessment_0 f_Mycotic_Settlement_Of_Freshwater_Fishes_In_Egypt

[22] Hussien A, Ahmed I, Waled S, Omima A. A trial for Induction of Saprolegniosis in Mugel cephalus with Special Reference to Biologica I Control. J Amer Sci2010;6(6):6.

[23] Shimaa El sayed MA. Studies on the causative agents of mycotic diseases in freshwater fishes. Cairo Unvi. 2007.

[24] Hassan A, Hassan A, El-Shafei H, El Ahl M, Abd El-Dayem R. Detection of aflatoxigenic moulds isolated from fish and their products and its public health significance. Nature Science. 2011;9(9):106-14.

[25] Atef HA, Howayda M, El S, Mogda K, Mansour S, Snosy A, et al. Effect of microbiological contamination and pollution of water on the health status of fish. European J AcadEssays. 2016;3(5):178-92.

[26] Moeller RB. Fungal diseases of fish, California Animal Health and food safety laboratory system. University of California. 2010.

[27] Claireaux G, Webber D, Kerr S, Boutilier R. Physiology and behaviour of free-swimming Atlantic cod (Gadus morhua) facing fluctuating temperature conditions. J Exper Bio 1995;198(1):49-60.

[28] Rezeka S. Integumentary mycosis in cultured freshwater fish and shrimps. 1991.

[29] Ali Shelm. Studies on the causative agents of mycotic diseases in fresh water fishes. M.V.Sc Thesis (Microbiology). Cairo University 2007.

[30] Logotheti M, Kotsovili-Tseleni A, Arsenis G, Legakis NI. Multiplex PCR for the discrimination of $A$. fumigatus, $A$. flavus, $A$. niger and $A$. terreus. J $\begin{array}{lll}\text { Micro } \quad \text { Methods. 2009;76(2):209-11. } & \text {. }\end{array}$ https://doi.org/10.1016/j.mimet.2008.10.006

[31] Sarjito, Condro Haditomo AH, Sabdaningsih A, Desrina, Prayitno SB.Aspergillus Diversity Associated with Fungal Diseases on Fish with Molecular Based. IOP Conference Series: Earth and Environmental Science. 2019;246:012035 . https://doi.org/10.1088/17551315/246/1/012035

[32] Tiwari K, Jadhav S, Kumar A. Morphological and molecular study of different Penicillium species. Middle-East J Sci Res. Middle-East J Sci Res 2011;7(1):203-10.

[33] Lim YH, Do-Hyun L. Rapid PCR method for detecting Candida albicans using primers derived from the integrin-like protein gene aINT1 of Candida albicans. J Micro 2000;38(2):105-8.

[34] Ecker DJ, Sampath R, Li H, Massire C, Matthews HE, Toleno D, et al. New technology for rapid molecular diagnosis of bloodstream infections. Expert Review of Molecular Diagnostics. 2010;10(4):399-415. https://doi.org/10.1586/erm.10.24

[35] Yang Y-L, Hung C-C, Wang A-H, Tseng F-C, Leaw SN, Tseng Y-T, et al. Oropharyngeal colonization of HIV-infected outpatients in Taiwan by yeast pathogens. J clin micro 2010;48:2609-12. https://doi.org/10.1128/JCM.00500-10

[36] Amgad Moawad, Ahmed Noor El Deen, Nadia Mahfouz, Salwa Helmy, and Yasmen Hashem (2019): Phenotypic and molecular identification of yeasts isolated from cultured Tilapia (Oreochromis niloticus) in Kafer- El Sheikh Province, Egypt. Slovenian Veterinary Research, Vol.56 Suppl22.56. https://doi.org/10.26873/SVR-803-2019

[37] Logotheti M, Kotsovili-Tseleni A, Arsenis G, Legakis NI.( 2009). Multiplex PCR for the discrimination of A. fumigatus, A. flavus, A. niger and A. 
terreus. Journal of Microbiol Methods. ; 76(2):209-11. https://doi.org/10.1016/j.mimet.2008.10.006

[38] Young H, and Do-Hyun L. (2000). Rapid PCR method for detecting Candida albicans using primers derived from the Integrin-like Protein Gene alNT1 of Candida albicans. J Microbiol 105-108.

[39] Faggi E, Pini G, Campisi E, Bertellini C, Difonzo E \& Mancianti F.(2001).Application of PCR to distinguish common species of penicillins.J Clin Micro 39, 3382 - 3385. https://doi.org/10.1128/JCM.39.9.3382-3385.2001

[40] White T., Bruns A, LeeS. and Taylor.( 1990).Amplification annd direct sequencing of fungal ribosomal RNA genes for phylogenetics. PCR Protocols: A Guide to Methods and Applications, 1990; https://doi.org/10.1016/B978-0-12-372180-8.50042-1 